УДК 634.717:58.032.3

(C) 2018

Телепенько Ю. Ю., молодший науковий співробітник

(науковий керівник - кандидат сільськогосподарських наук В. О. Сіленко)

Інститут садівництва НААН України

\title{
ПОРІВНЯЛЬНА ОЦІНКА ПОСУХОСТІЙКОСТІ СОРТІВ ОЖИНИ (RUBUS L.) В УМОВАХ ЗАХІДНОГО ЛІСОСТЕПУ УКРАЇНИ
}

\section{Рецензент - кандидат біологічних наук О. І. Китаєв}

У статті наведено результати лабораторних досліджень впливу високих температур на фізіологічний стан листя 25 сортів ожини в умовах західного Лісостепу України. У лабораторних умовах досліджено водно-фізичні властивості, такі як водоутримувальна здатність, дефійит вологи й оводненість тканин листя. За стійкістю до втрати вологи досліджувані сорти розділено на три групи: високопосухостійкі (Black Diamond, Black Pearl, Chief Joseph, Heaven can Wait, Loch Tay, Natches, Orkan, Насолода, Chester, Ouachita), середньопосухостійкі (Karaka Black, Adriene, Asterina, Brzezina, Cacanska Bestrna, Navaho, Tornfree, Cадове чудо, Jumbo, Kiowa, Reuben) та сорти з низькою стійкістю (Apache, Black Butte, Black Magic, Triple Crown). Найнижчим показником водного дефіuиту характеризуються сорти Natches ma Apache, а найвищчм - Black Butte. Найвищу оводненість тканин листків ожини відмічено у сортів Loch Tay (58,9\%), Tornfree (59,7\%) ma Brzezina (60,8\%). Наймени оводненими є тканини сортів Navaho ma Black Butte (51,4 ma 51,7\% відповідно).

Ключові слова: посухостійкість, адаптивність, водоутримуюча здатність, оводненість, дефіичит вологи, сорт.

Постановка проблеми. У життєвому та річному циклах рослин немає важливих чи неважливих періодів - розвиток рослини йде безперервно і зовнішні фактори кожного періоду впливають на нього. Проведення фізіологічних досліджень дає можливість виділити найбільш адаптовані сорти для культивування за певних кліматичних умов та в подальшому удосконалити технологію їх вирощування, що не тільки дасть змогу рослинам подолати високе стресове навантаження, а й підвищить якість урожаю [2]. Вегетаційний період в останні роки характеризується нестабільним зволоженням, часто відмічаються періоди без опадів, які спричиняють грунтову та повітряну посухи. Такі перепади температур та недостатня кількість опадів негативно впливають на ріст і розвиток рослин. Встановлено, що після посушливих періодів відмічається зниження морозостійкості на 4-6 ${ }^{\circ} \mathrm{C}$ [4]. Відомо [6], що вода $\epsilon$ розчинником і водночас середовищем, у якому відбуваються переміщення ре- човин та їх обмін, а їі висока теплоємність стабілізує температуру рослин. За нестачі вологи у плодових рослин зупиняється ріст, в'яне та обсипається листя і плоди, знижується закладання генеративних бруньок, а відповідно й урожайність, не тільки у рік посухи, а й на наступний, різко знижується якість плодів.

Вивчення посухостійкості фізіологічними методами краще проводити в періоди найбільшої напруги стресових факторів, у посушливі та особливо жаркі періоди, у період 3 кінця росту пагонів до початку старіння листків [8]. Найбільш інформативними із лабораторно-польових методів вивчення посухостійкості є вивчення показників водного режиму листя: оводненості тканин, водного дефіциту та визначення водоутримувальної здатності.

Аналіз останніх досліджень та публікацій, у яких започатковано розв'язання проблеми. Дослідженнями О. В. Сердюка [9] встановлено, що параметри втрати води рослинами ожини у порівнянні 3 аналогічними дослідженнями Ю. Ю. Андрусика $з$ малиною, у 1,5 рази менші. Це вказує на вищу потенційну посухостійкість ожини. Коренева система ожини сильно розвинена і залягає на глибині до 1,5 м [10]. Проте ожина, як і будь-які інші рослини, не може оптимально рости і плодоносити без достатнього вологозабезпечення, оскільки волога необхідна для формування плодів, а сильний листковий апарат випаровує значну кількість води. У листках рослин наявні механізми, які регулюють витрати води, в залежності від умов навколишнього середовища. Відомо [5], що рослини здатні регулювати випаровування вологи зі своїх тканин за рахунок роботи продихів. Процес транспірації у розрізі культур суттєво відрізняється, спостерігається і різна іiі інтенсивність між сортами у межах однієї культури. Сортимент ожини доволі обмежений не тільки на території зони Лісостепу, а й всієї країни через відсутність достатньої кількості сортів вітчизняної селекції. На даний час до «Державного Реєстру сортів рослин придатних до поширення в Україні» включені 5 


\section{СІЛЬСЬКЕ ГОСПОДАРСТВО. РОСЛИННИЦТВО}

сортів ожини, з яких два - селекції П. 3. Шеренгового (НУБіП України). Проте у світі відомо вже понад 300 сортів ожини та малиноожинових гібридів, які є більш витривалими та продуктивними [10]. Тому на часі питання про детальне вивчення та добір сортів із високою адаптивною здатністю до стресових чинників. А в умовах глобального потепління актуальним стає створення сортів посухостійких і високоврожайних незалежно від температур і вологості повітря.

Мета дослідження - удосконалити сортимент ожини на підставі вивчення господарськобіологічних особливостей нових сортів та їх адаптивності у грунтово-кліматичних умовах західного Лісостепу України для подальшого сортовивчення та впровадження у селекційні програми.

Завдання досліджень полягало у визначенні впливу високих температур на фізіологічний стан листя 25 сортів ожини в умовах західного Лісостепу України.

Матеріал та методика дослідження. Дослідження проводили в умовах західного Лісостепу України на базі Інституту садівництва НААН України (м. Київ) у період найбільшого напруження водного режиму 2016-2017 рр. Об'єктами досліджень були 25 сортів ожини, а саме: Adriene, Apache, Asterina, Black Butte, Black Diamond, Black Magic, Black Pearl, Brzezina, Cacanska Bestrna, Chester, Chief Joseph, Heaven can Wait, Jumbo, Karaka Black, Kiowa, Loch Tay, Natches, Navaho, Orkan, Ouachita, Reuben, Tornfree, Triple Crown, Насолода (контроль) та Садове чудо. Рослини висаджені за методикою колекційного сортовивчення $[8,1]$ восени 2014 року. Схема садіння рослин $3,00 \times 1,25$ м. Агротехнічні заходи проводили згідно iз загальноприйнятою технологією вирощування ягідних культур.

Лабораторні дослідження проводили в Лабораторії фізіології рослин і мікробіології IC НААН України.

Вивчення водно-фізичних властивостей листя досліджуваних сортів проводили згідно 3 «Программой и методикой сортоизучения плодовых, ягодных и орехоплодных культур» [8].

Статистичну та математичну обробку отриманих даних проводили методом дисперсійного аналізу за допомогою прикладних комп’ютерних програм [3, 7].

Результати досліджень. 3 метою отримання узагальненої оцінки посухостійкості сортів ожини наведено середні значення отриманих результатів за період досліджень (2016-2017рр.).

Аналізуючи наведені показники водоутриму- вальної здатності (див. табл.), зафіксовано різну інтенсивність втрати води у розрізі досліджуваних сортів.

Вивчення динаміки змін водоутримуючої здатності показало, що найбільш інтенсивно листки втрачали воду у перші 2 години після зважування. Так, найбільший відсоток втрати води зафіксовано у сортів Садове чудо $(9,5 \%)$ та Black Butte (9,2 \%). Найменший показник втрати вологи відмічено у сорту Natches $(2,7 \%)$. Контрольний сорт вітчизняної селекції Насолода за перші 2 години втратив 4,6 \% води.

За 4 години експозиції листки втрачали від $5,5 \%$ (Natches) до $16,3 \%$ (Black Butte Blackberry), а за 6 годин - від 7,50 (Natches) до $24,8 \%$ води (Black Butte Blackberry). Відсоток втрати води у сорту-контролю зафіксовано на рівні 8,1 (через 4 години) та 11,9\% (6 годин).

Оскільки посуха в умовах оточуючого середовища може бути досить тривалою, то важливим показником під час вивчення посухостійкості сорту $€$ дослідження втрати води після добової експозиції. Загалом, на основі отриманих даних слід відмітити copт Natches, який показав стабільно високу водоутримувальну здатність (26,30 \%), що свідчить про високий рівень адаптивності до умов посухи. Також істотно нижчим показником водоутримувальної здатності характеризуються сорти Chief Joseph $(33,8 \%)$, Chester $(34,1)$ та Orkan $(34,5 \%)$. Найменш посухостійкими виявились сорти Black Magic, Black Butte Blackberry та Apache, в яких у середньому за роки досліджень зафіксовано найвищі втрати води (53,9, 52 та 49,8 \% відповідно).

Проаналізувавши вищевикладений матеріал, досліджувані сорти за стійкістю втрати вологи можна поділити на групи, а саме:

- високопосухостійкі (втрати води за 24 годи-

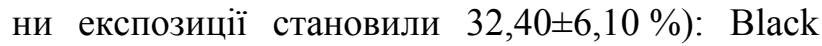
Diamond, Black Pearl, Chief Joseph, Heaven can Wait, Loch Tay, Natches, Orkan, Насолода, Chester, Ouachita;

- середньопосухостійкі (втрати води 44,55 $\pm 3,45 \%$ ): Karaka Black, Adriene, Asterina, Brzezina, Cacanska Bestrna, Navaho, Tornfree, Caдове чудо, Jumbo, Kiowa, Reuben;

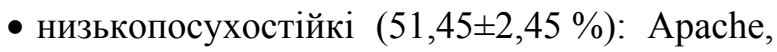
Black Butte, Black Magic, Triple Crown.

Оцінка посухостійкості рослин за водним дефіцитом проведена за такою класифікацією: 10$15 \%$ - помірний вплив посухи; більше $18 \%$ істотне напруження водного режиму, що викликає незворотні порушення у структурній будові мембран [7]. 
СІЛЬСЬКЕ ГОСПОДАРСТВО. РОСЛИННИЦТВО

Водоутримуюча здатність сортів ожини (середнє за 2016-2017 рр.)

\begin{tabular}{|c|c|c|c|c|}
\hline \multirow{2}{*}{ Назва сорту } & \multicolumn{4}{|c|}{ Втрати води після експозиції, \% } \\
\hline & 2 год. & 4 год. & 6 год. & 24 год. \\
\hline \multicolumn{5}{|c|}{ Сланкі } \\
\hline Black Butte & 9,20 & 16,30 & 24,80 & 52,00 \\
\hline Black Diamond & 4,60 & 8,60 & 11,90 & 37,20 \\
\hline Black Pearl & 4,50 & 8,80 & 13,10 & 35,50 \\
\hline Karaka black & 7,80 & 13,70 & 22,30 & 46,00 \\
\hline \multicolumn{5}{|c|}{ Напівпряморослі } \\
\hline Adriene & 8,10 & 14,40 & 21,20 & 44,70 \\
\hline Asterina & 5,70 & 11,60 & 18,4 & 48,00 \\
\hline Brzezina & 3,60 & 8,80 & 12,70 & 41,10 \\
\hline Cacanska bestrna & 4,70 & 9,80 & 15,30 & 46,30 \\
\hline Chief Joseph & 4,80 & 8,20 & 11,30 & 33,80 \\
\hline Heaven can Wait & 4,50 & 12,10 & 15,50 & 38,50 \\
\hline Loch Tay & 3,40 & 7,20 & 9,90 & 36,00 \\
\hline Natches & 2,70 & 5,50 & 7,50 & 26,30 \\
\hline Navaho & 5,00 & 10,70 & 17,10 & 42,20 \\
\hline Orkan & 4,50 & 8,10 & 11,70 & 34,50 \\
\hline Tornthree & 7,60 & 11,20 & 17,80 & 47,20 \\
\hline Triple crown & 5,30 & 10,30 & 14,80 & 49,00 \\
\hline Насолода (к) & 4,60 & 8,10 & 11,90 & 37,30 \\
\hline Садове чудо & 9,50 & 14,10 & 17,80 & 48,70 \\
\hline \multicolumn{5}{|c|}{ Пряморослі } \\
\hline Apache & 6,80 & 13,90 & 19,30 & 49,80 \\
\hline Black Magic & 8,30 & 13,80 & 22,40 & 53,90 \\
\hline Chester & 3,00 & 6,40 & 9,50 & 34,10 \\
\hline Jumbo & 6,20 & 13,50 & 19,20 & 46,70 \\
\hline Kiowa & 7,30 & 14,00 & 18,90 & 47,40 \\
\hline Ouchita & 3,30 & 7,20 & 11,80 & 35,90 \\
\hline Reuben & 4,50 & 8,30 & 12,70 & 41,10 \\
\hline HIP05 & 0,12 & 0,27 & 0,42 & 0,95 \\
\hline
\end{tabular}

$\mathrm{F}<\mathrm{F}$ крит.

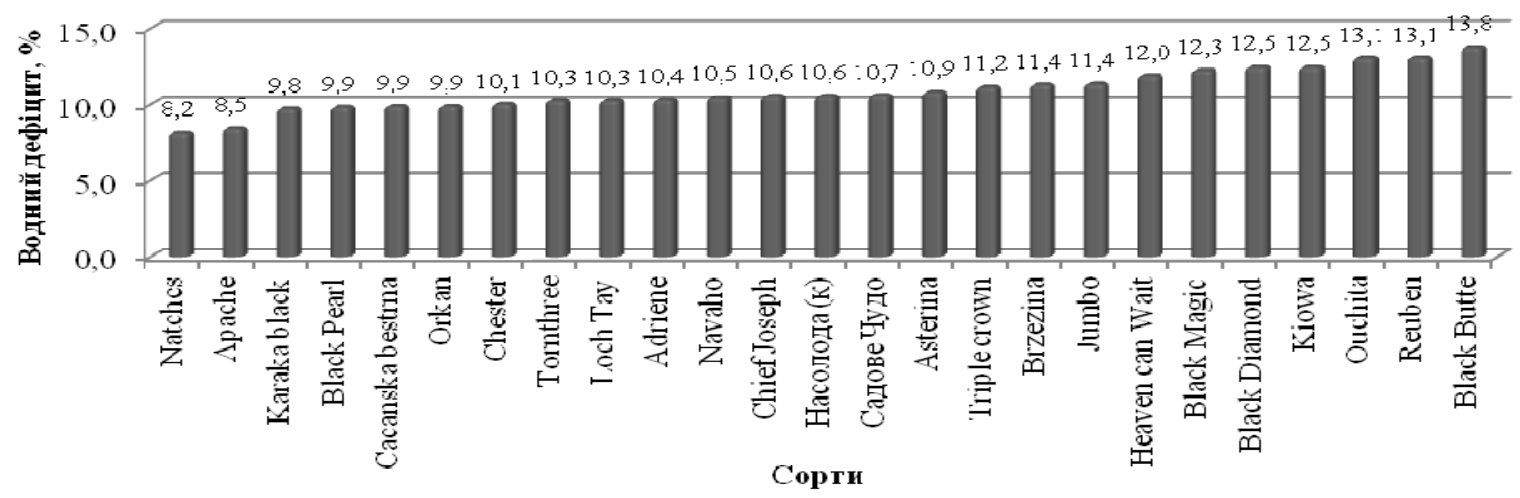

Рис. 1. Водний дефіцит листків ожкини, \% (середнє за 2016-2017 рр.) 


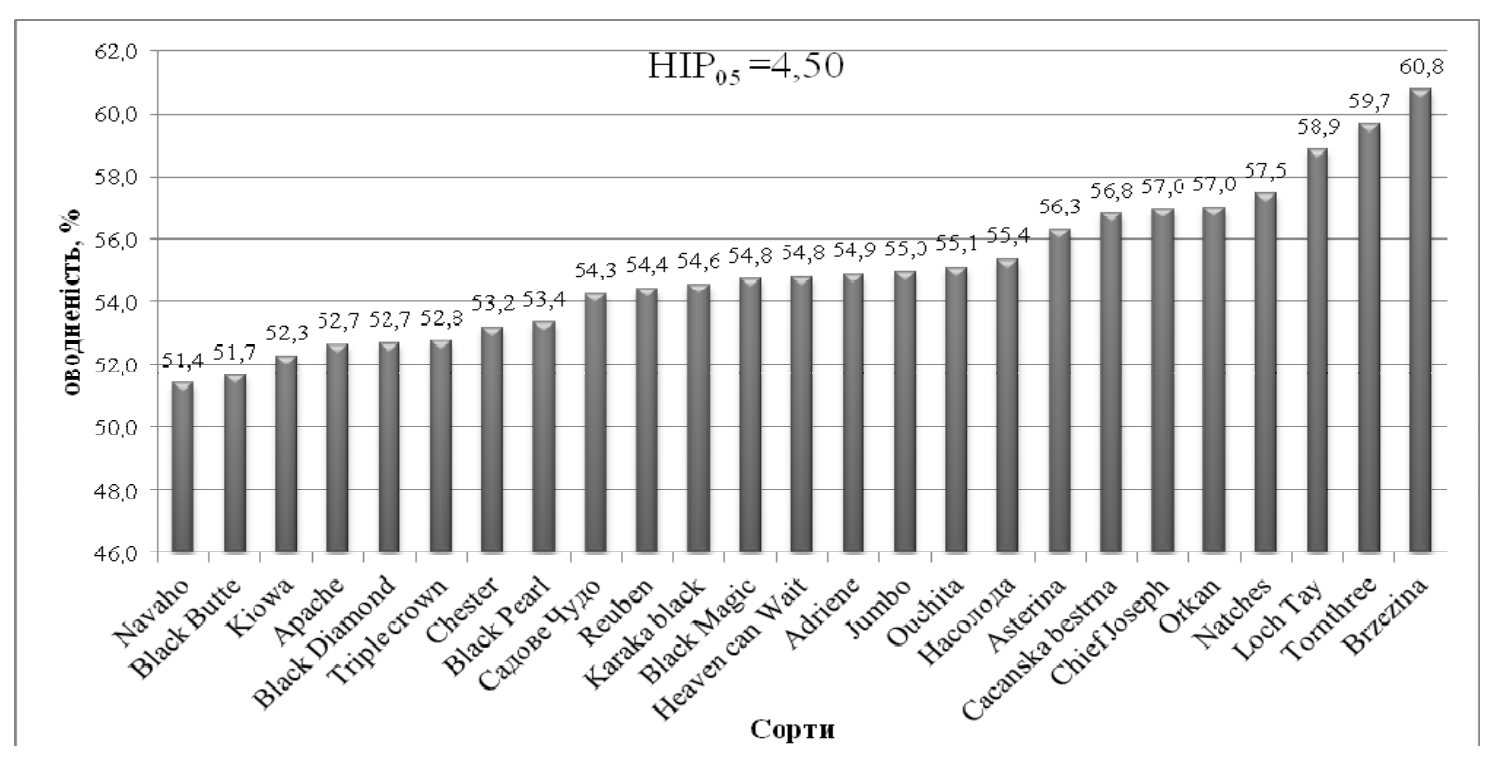

Рис. 2. Оводненість тканин листків ожини, \% (середнє за 2016-2017 рр.)

Необхідно відмітити, що в розрізі досліджуваних сортів показник водного дефіциту не перевищує 13,8 \%, що підтверджує факт досить високої посухостійкості рослин ожини (рис. 1). Загалом, у розрізі досліджуваних сортів не зафіксовано істотної різниці між значеннями водного дефіциту. Проте найменшим дефіцитом вологи характеризується сорт Natches, 3 показником $8,2 \%$, а найбільшим - Black Butte $(13,8 \%)$, що вказує на дещо нижчий його адаптивний потенціал в умовах посухи.

Важливим елементом оцінки фізіологічного стану рослин у період посухи є їх здатність підтримувати оптимальний рівень оводненості тканин листків. Зменшення рівня оводненості в рослині може призвести до незворотніх процесів, таких як зменшення приростів пагонів та коренів, передчасного в'янення листків, навіть до усихання та скидання їх, зменшення кількості запасних поживних речовин і порушення асиміляції $\mathrm{CO}_{2}$. Проте такі анатомічні ознаки, як оводненість та водний дефіцит, використовують лише як допоміжний критерій для визначення посухостійкості [7].

Рівень оводненості досліджуваних сортів ожини знаходився у межах від 51,4 до 60,8 \%. Під час проведення дисперсійного аналізу отриманих даних встановлено, що достовірно вищий рівень оводненості $\left(\mathrm{HIP}_{05}=4,50\right)$ має лише сорт Brzezina $(60,8 \%)$.

\section{БІБЛІОГРАФІЯ}

1. Андрієнко М. В. Методика вивчення сортів і форм ожини / М. В. Андрієнко. - К., 1992. - 21 с.

2. Гудковский В. А. Основные стрессфакторы и механизмы повреждения растений /
Показники решти сортів істотно не відрізняються від контрольного.

Висновок. За результатами лабораторних досліджень водно-фізичних властивостей листків досліджувані сорти ожини за стійкістю до втрати вологи розділено на три групи. Виділено високопосухостійкі (Black Diamond, Black Pearl, Chief Joseph, Heaven can Wait, Loch Tay, Natches, Orkan, Насолода, Chester, Ouachita), середньопосухостійкі (Karaka Black, Adriene, Asterina, Brzezina, Cacanska Bestrna, Navaho, Tornfree, Caдове чудо, Jumbo, Kiowa, Reuben) та сорти 3 низькою стійкістю (Apache, Black Butte, Black Magic, Triple Crown). Сорти 3 середнім рівнем посухостійкості ризиковано культивувати без застосування зрошення, а 3 низьким - лише за наявності зрошення. Встановлено, що найнижчим показником водного дефіциту характеризуються сорти Natches та Apache, а найвищим - Black Butte. Найвищу оводненість тканин листків ожини відмічено у сортів Loch Tay $(58,9 \%)$, Tornfree $(59,7 \%)$ та Brzezina (60,8 \%). Найменш оводненими є тканини сортів Navaho та Black Butte (51,4 та 51,7 \% відповідно). За комплексом визначених показників сорт Black Butte характеризується найнижчою адаптивною здатністю до посухи порівняно 3 рештою сортів, a Natches найвищою, що дає змогу рекомендувати його для впровадження у селекційні роботи як носія гену посухостійкості.

В. А. Гудковский, Н. Я. Каширская, Е. М. Цуканова // Садівництво. - Вип. 55. - 2004. - С. $283-$ 290. 
3. Доспехов Б. А. Методика полевого опыта / Б. А. Доспехов. - М. : Агропромиздат, 1985. $351 \mathrm{c}$.

4. Кривошапка В. А. Кліматичні зміни та ризики при вирощуванні плодових і ягідних культур в умовах північної частини Лісостепу України / В. А. Кривошапка, М. О. Бублик, О. І. Китаєв, В. В. Груша // Садівництво. - Вип. 71. - 2017. - C. 130-138.

5. Кушниренко М. Д. Физиология водообмена и засухоустойчивости плодовых растений / [под ред. проф. П. А. Генкеля]. - Кишинев : ШТИИИНЦА, 1975. - 214 с.

6. Лархер В. Экология растений / [перевод Д. П. Викторова; под. ред. Т. А. Работнова]. - М. : Мир, 1978. -282 с.
7. Меженський В. М. Основи наукових досліджень у садівництві. Розрахунки в Microsoft Exel : Навч. посібник / В. М. Меженський. - К., 2017. $-212 \mathrm{c}$.

8. Программа и методика сортоизучения плодовых, ягодных и орехоплодных культур / [под ред. Е. Н. Седова, Т. П. Огольцовой]. Орел : ВНИИСПК, 1999. - 608 с.

9. Сердюк О.В. Адаптивність нових сортів і гібридів ожини до умов правобережної підзони Західного Лісостепу України : автореферат дис. на здобуття наукового ступеня к. с.-г. н. - К., 2010. $-22 \mathrm{c}$.

10. Шеренговий П. 3. Сучасні технології вирощування ожини та малино-ожинових гібридів / [за ред. П. З. Шеренгового]. - К., 2013. - 132 с. 